\title{
ICE THICKNESS USING GROUND PENETRATING RADAR AT ZNOSKO GLACIER ON KING GEORGE ISLAND
}

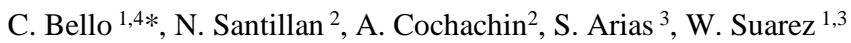 \\ ${ }^{1}$ Water Resources Graduate Program - National Agrarian University La Molina, Lima, Peru - (20190813, \\ wsuarez)@lamolina.edu.pe \\ ${ }^{2}$ National Water Authority, Lima, Peru - (nsantillan, acochachin)@ ana.gob.pe \\ ${ }^{3}$ National Service of Meteorology and Hydrology of Peru, Lima, Peru - (sarias, wsuarez)@senamhi.gob.pe \\ ${ }^{4}$ Ministry of Foreign Affairs of Peru - cbello@rree.gob.pe
}

KEY WORDS: Ground penetrating radar, ice thickness, Znosko glacier, Antarctic Peninsula, electromagnetic waves, glaciology.

\section{ABSTRACT:}

Ground Penetrating Radar (GPR) survey was carried out to estimate the ice thickness and mapping the bedrock topography at Znosko glacier on King George Island, Antarctic Peninsula during 25 $5^{\text {th }}$ Peruvian Antarctic Expedition (2018). GPR surveying did at $5.2 \mathrm{MHz}$ frequency with a $16 \mathrm{~m}$ antenna gap (transmitter and receiver). The mean ice thickness profiles vary from 7 to $123 \mathrm{~m}$ across the $350 \mathrm{~m}$ profile length. This high-resolution survey also identified a different type of ices and glaciological features which will help in modelling the nature of the glaciers in the future.

\section{INTRODUCTION}

Around $71 \%$ of the earth's water stored in oceans and glaciers. Polar regions (Antarctic and Arctic) are crucial for regulating the world climate, but they are vulnerable to the impacts of global warming (Teleti, Luis, 2013).

The Special Report on the Ocean and Cryosphere in a Changing Climate published by the Intergovernmental Panel on Climate Change reveals that recent studies detected that Antarctic Peninsula (AP) and West Antarctic Ice Sheet (WAIS) had lost ice mass since 1992, and the rate of retreat has been increasing since 2006 (IPCC, 2019). Suck phenomena in AP caused the disintegration of ice shelves, retreat and thinning of glaciers (Friedl et al, 2018) particular on King George Island.

Knowledge on ice volume and ice thickness distribution are essential parameters for glaciological applications especially for simulate glacier dynamics (Farinotti et al, 2009) and may provide information to understand the effect of global warming (Singh et al., 2011; Farinotti et al, 2019). Direct (ice drilling and excavations) and indirect (gravimetry, radio-echo and seismic soundings) explorations techniques have used to quantify glacier thickness (Gärtner-Roer et al, 2014; Farinotti et al, 2009). Besides, recent advances in remote sensing technology have made to obtain data with an excellent spatial resolution (GärtnerRoer et al, 2014).

Ground Penetrating Radar (GPR) is a non-destructive technique, based on the propagation and reflection of electromagnetic waves to acquire information from the subsurface materials (air, water, sediment, ice) and the interfaces between them (Gärtner-Roer et al, 2014; Oberreuter et al, 2014, Singh et al, 2011). Electromagnetic waves propagation depends on the electric permittivity, electrical conductivity and magnetic permeability (Oberreuter et al, 2014). In glaciology, low frequency GPR (approx. 2-220 MHz) is useful for ice thickness observations (Oberreuter et al, 2014).

Preliminary results of the GPR survey carried out to estimate the ice thickness at Znosko glacier on King George Island, Antarctic Peninsula reported.

The present work shows the initial stage of a broader action that seeks to know the changes in the ice masses located on King
George Island, through the use of GPR, picture by drone and mass balance measurements from monitoring the glacier Znosko.

\section{STUDY AREA}

King George Island (KGI) is the largest of the South Shetland Islands situated at $130 \mathrm{~km}$ from the northwestern tip of the Antarctic Peninsula and has an area of $1250 \mathrm{~km}^{2}$ (Simões et al., 1999). The humid and warm air masses from the South Pacific Ocean influenced the west coast of the AP, while cold and dry air masses from the Weddell Sea affected the east coast (Falk et al, 2018). The highest elevation reaches more than $700 \mathrm{~m}$ in the central ice dome. Almost $90 \%$ of the island covered by a polythermal ice cap and influenced by maritime climate conditions (Falk et al, 2018, Ruckamp et al, 2010, Simões et al, 1999).

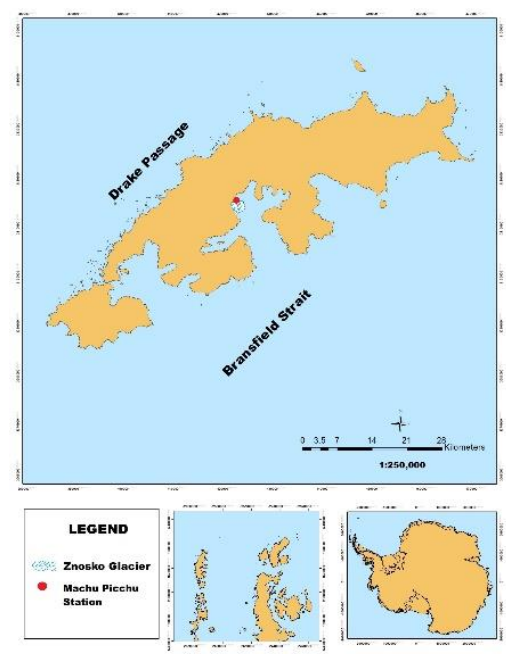

Figure 1. Location map

In recent decades, the glaciers on KGI have shown retreat and loss of thickness associated with rising air temperatures. Znosko

\footnotetext{
* Corresponding author
} 
glacier is located (Figure 1) in King George Island South Shetland Islands of the Antarctic Peninsula, has an area of 2.4 $\mathrm{km}^{2}$ with an elevation range from 2 to $256 \mathrm{~m}$ with an average slope of $15 \%$.

\section{METHODS}

Since 2013 the National Service of Meteorology and Hydrology of Peru (SENAMHI) and the National Water Authority (ANA) participate in the Peruvian Antarctic Expeditions with a project that intends to study the ice volume changes and mass balance at Znosko glacier on KGI.

During the $25^{\text {th }}(2018)$ and $26^{\text {th }}$ (2019) Peruvian Antarctic Expedition, a GPR survey was carried out, and a total of 19 stakes located in the ablation zone of the Znosko glacier, respectively. Also, a topographic survey was conducted by photogrammetry method by the National Geographic Institute (IGN).

For the present study, GPR profiles were performed for three days during the $25^{\text {th }}$ Peruvian Antarctic Expedition in February 2018. The GPR system consists of a transmitter and a receiver, with corresponding antennae (bistatic arrangement). We use a radar HF unit made by Unmanned Industrial with antennas at a central frequency of $5.2 \mathrm{MHz}$ (16 m antenna length). The radar survey was performed by two operators (transmitter and receiver) on foot with a $25 \mathrm{~m}$ of the separation distance between them. 8 profiles measured with a length of approximately $350 \mathrm{~m}$. Postprocessing and data analyses carried out using Reflexw V7.5.5 (Sandmeier Scientific Software).

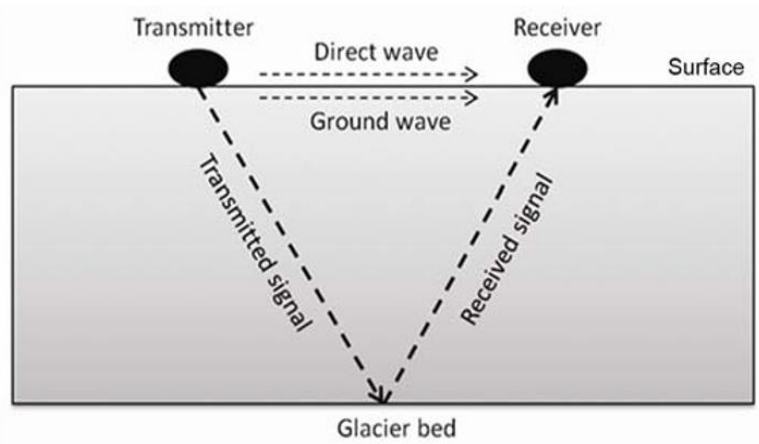

Figure 2. GPR operational principles. Figure is from Singh, 2012.

Unmanned Aerial Vehicle (UAV) photogrammetry has emerged as an on-demand method to generate high-resolution datasets, including DEMs and orthorectified images (orthophotos). During the $26^{\text {th }}$ Peruvian Antarctic Expedition, we used a self-assembled UAV platform equipped with a Sony Alfa 500/RGB digital camera which has a $16 \mathrm{~mm}$ focal length and a 23-megapixel resolution. The Quadcopter has an onboard navigation system, and the whole platform weighs approximately $3 \mathrm{~kg}$. DEM composed with $5 \mathrm{~m}$ of exceptional resolution and accuracy of $0.7 \mathrm{~cm}(\mathrm{X})$ and $(\mathrm{Y})$ in the horizontal directions and $2 \mathrm{~cm}(\mathrm{Z})$ in the vertical direction.

\section{RESULTS}

Figure 3 shows the colour-coded ice thickness along with all acquired GPR profiles, indicating that the subglacial topography has a minimal roughness.

During the radar survey, data collected over $350 \mathrm{~m}$. GPR sections at Znosko Glacier show the ice thickness distribution varies at different parts in the tongue of the glacier. Ice thickness ranges from around $7 \mathrm{~m}$ at the eastern margin to a maximum ice thickness of $123 \mathrm{~m}$ on the western part of the central flat area (Figure 4). A contribution to the difference between ice thickness and surface elevation change could result from basal melting related to the thermal regime and ice flow conditions of the ice cap in KGI (Ruckamp et al, 2010, Simões et al, 1999).

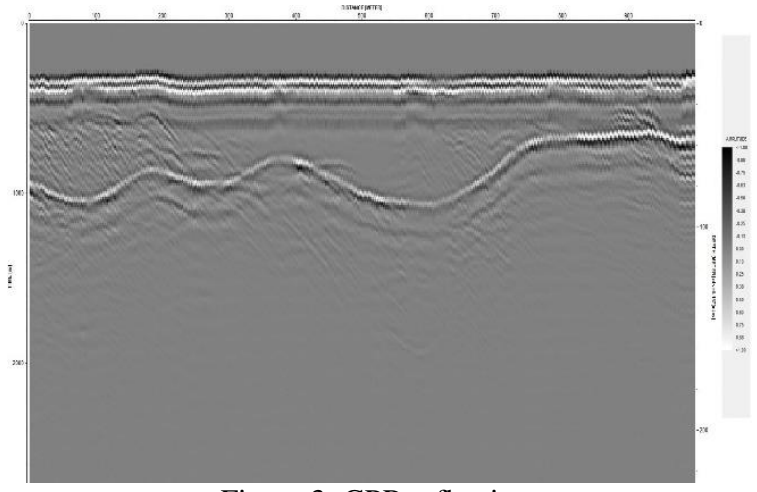

Figure 3: GPR reflection.

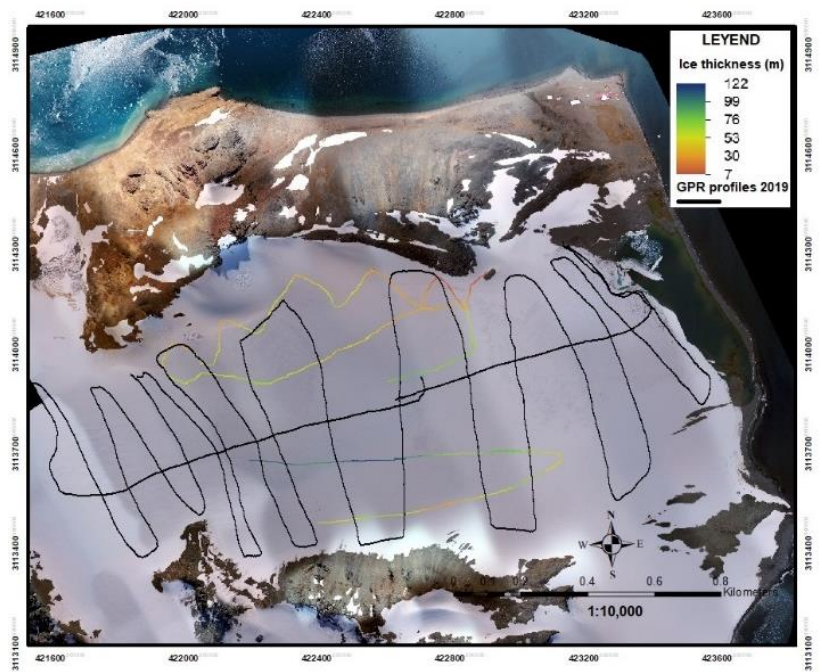

Figure 4. Ice thickness distribution Znosko glacier.

\section{CONCLUSIONS}

GPR is a non-destructive technique with the potential to estimate the ice thickness directly and identify englacial subsurface features. However, in many cases, additional information from different sources is required to interpret the radar data. A lowfrequency antenna used for the GPR survey carried out in the 2018 summer. The study has shown that Znosko glacier thickness changed from 7 to $123 \mathrm{~m}$ across the $350 \mathrm{~m}$ profile length. The mass balance loss for Znosko glacier was around $2.41 \mathrm{~m} /$ per year (until $80 \mathrm{~m}$ above sea level). The next step will be the comparison between mass changes obtained from glaciological measurements and the geodetic method to assess the temporal evolution of glacier mass balance in recent years. Also, through atmosphere-ocean general circulation models (AOGCMs) simulate the effect of climate change on the mass balance of Znosko glacier.

\section{ACKNOWLEDGEMENTS}

The National Antarctic Program of Peru supported this study. Fieldwork in Antarctica was carried out in cooperation with the National Geographic Institute (IGN) and Glaciar + project (CARE and Zurich University) the Swiss cooperation in Peru for the training in the GPR system. This study is part of a PhD research from the Water Resources Graduate Program - National Agrarian University. 


\section{REFERENCES}

Falk, U., López, AD., Silva-Busso, A. 2018: Multi-Year Analysis of Distributed Glacier Mass Balance Modelling and Equilibrium Line Altitude on King George Island, Antarctic Peninsula, The Cryosphere, 12(4), 1211-1232.

Farinotti, D., Huss, M., Bauder, A., Funk, M., Truffer, M. 2009: A method to estimate ice volume and ice-thickness distribution of apine glaciers. Journal of Glaciology, 55(191), 422-430.

Friedl, P., Seehaus, T., Wendt, A., Braun, M., Hoppner, K. 2018:

Recent dynamic change on Fleming Glacier after the disintegration of Wordie Ice Shelf, Antarctic Peninsula. The Cryosphere, 12(4), 1347-1365.

Intergovernmental Panel on Climate Change - IPCC. 2019: Special Report on the Ocean and Cryosphere in a Changing Climate.

Oberreuter, J., Uribe, J., Zamora, R., Gacitua, G., Rivera, A. 2014: Ice Thickness measurements in Chile using radio echo sounding. Geoacta, 39(1), 108-122.

Gärtner-Roer, I., Naegeli, K., Huss, M., Knecht, T., Machguth, H., Zemp, M. 2014: A database of worldwide glacier thickness observations. Global and Planetary Change, 122, 330-344.

Rückamp, M., Blindow, N., Suckro, S., Braun, M., Humbert, A. 2010: Dynamics of the ice cap on King George Island, Antarctica: field measurements and numerical simulations. Annals of Glaciology, 51(55), 80-90.

Singh, K., Datt, P., Sharma, V., Ganju, A., Mishra, V., Parashar, A., Chauchan, R. 2011: Snow depth and snow layer interface estimation using Ground Penetrating Radar. Current Science, 100(10), 1532-1539.

Simões, J., Bremer, U., Aquino, F., Ferron, F.A. 1999: Morphology and variations of glacial drainage basins in the King George Island ice field, Antarctica, Annals of Glaciology, 29, 220-224.

Teleti, P., Luis, A. 2013: Sea ice observations in Polar Regions: Evolution of Technologies in Remote Sensing, International Journal of Geosciences, 4 (7),1031-1050. 